\title{
Mantoux Tuberculin Skin Test
}

National Cancer Institute

\section{Source}

National Cancer Institute. Mantoux Tuberculin Skin Test. NCI Thesaurus. Code C85997.

A tuberculin skin test where a standard dose of 5 T uberculin units of purified protein derivative is injected under the skin of the inner surface of the forearm. Results are read 48-72 hours later. 